\title{
The Body Natural of a Queen: Mary, James, Horestes
}

\author{
KAREN ROBERTSON
}

"Scotland is a quagmire," William Cecil commented to his correspondent, Sir Henry Sidney, on April 23, 1567, two months after the murder of Henry Stuart, Lord Darnley, and eleven days after Bothwell's acquittal for that murder. Cecil continues, "Nobody seems to stand still, the most honest desire to go away, the worst tremble with the shaking of their conscience."1 His words fittingly describe the confusing chronology and obscure motivations in the tribal and religious conflicts which led to the murder of a king and the deposition of Mary Queen of Scots. Perspectives on Mary have been further distorted by the activities of Catholic and Protestant propagandists eager to further or block her as appropriate heir to Elizabeth I of England, making the figure of the woman difficult to discern behind the mythologizing which represents her as Catholic martyr or Protestant Jezebel. This paper considers the particular problems provoked by the reproducing body natural of a queen regnant, that aspect of her sovereignty in which she is most markedly different from a king. Mary Queen of Scots was a woman who attempted, unsuccessfully, to integrate sovereignty with biological maternity. ${ }^{2}$

In 1567-1568, the body of Mary Queen of Scots marked the intersection of a number of ideological systems - courtly love, Roman Catholicism, sovereignty, marriage, and maternity. The first four years of Mary's personal rule in Scotland attest to her successful negotiation of several of these systems. It was the marriage and subsequent pregnancy of the sovereign which precipitated the crisis which cost her her crown. Constance Jordan's careful analysis of Tudor political tracts suggests a positive development in the political analysis of sovereignty which criticized notions of "natural" sovereignty as exclusively masculine. ${ }^{3}$ Despite such positive developments in theory, it was Mary's participation as a queen regnant in the institutions of marriage and motherhood which precipitated her disastrous fall. Her 


\section{6 / Renaissance and Reformation}

pregnant body makes prominent the peculiarities of her situation as a female prince, for the female ruler who produces an heir makes clear that the Tudor notion of the king's two bodies - one, the body natural, subject to infirmity and death, the other, the body politic, infallible and immortal - is a legal metaphor. The sovereign queen's body, a sufficiently complex figure at the head of the ruling hierarchy in the Renaissance, during gestation and birth literally encloses the continuity of her rule. As reproducing female monarch, Mary tested in practice the advantages of marriage and production of an heir proposed to Elizabeth $I$ by any number of her counselors. For Mary the experiment was unfortunate.

This paper focuses on the body natural of a sovereign mother, by considering the events in Scotland surrounding the birth of James VI and I, the oblique commentary on those events made in the play Horestes by John Pikeryng, and the play's odd prescience about the dilemma faced by the adult James, nearly twenty years later, as shown in his letters written in the months following his mother's condemnation for treason and before her execution at Fotheringhay. In all three instances - event, interlude, letter - the body natural of the mother and the obligations owed to that body figure prominently.

The political crisis in Scotland that led to Mary's abdication is significantly bracketed between two pregnancies - the successful pregnancy which produced her heir, James VI, and the miscarriage in 1568 which preceded Mary's resignation in favor of her son. ${ }^{4}$ When Mary chose as her husband her second cousin, Henry Stuart, Lord Darnley, she united two claimants to the English throne, a seemingly strategic maneuver that proved disastrous. The marriage did succeed in one area, since Mary quickly became pregnant. Within five weeks of the pregnancy, Randolph, the English ambassador to Scotland, had reported it back to London. ${ }^{5}$ The pregnancy exacerbated Darnley's discontent. Although he had been named as king consort and proclaimed as King Henry, the name by which he was known - despite no permission from the Scottish Parliament - he desired the crown matrimonial which would guarantee his continuing rule in the event of Mary's death without an heir. ${ }^{6}$ A successful birth would preclude his chances for sole rule.

Mary was six months pregnant when her advisor, David Riccio, was torn from her skirts and within her earshot was stabbed to death by her husband and other lords. Riccio had 56 stab wounds in his body. ${ }^{7}$ The murder was reported in England as the action of the dishonored husband against his adulterous wife. Cecil believed that the murder of Riccio was provoked by Mary's adultery with her servant, or so he claimed in a letter to M. de Foix, 
who was shocked by the news. ${ }^{8}$ The suspicions of adultery between the Queen and her secretary were sufficiently persistent that decades later Henry IV could impugn with a witticism the legitimacy of James. He called James "the modern Solomon, since he was the son of David who played on the harp," a reference to Riccio's musical skill. ${ }^{9}$ Mary believed "the murder had been deliberately staged to produce the maximum amount of shock and horror in the hope that she would miscarry and die." 10 Mary's belief, held to the end of her life, makes clear the extreme vulnerability she felt during the murder and the anxiety she felt about the pregnancy. That belief is given further support by Darnley's subsequent indifference to her health. When Mary persuaded Darnley to rescue her from the rebel lords and they were riding furiously from Edinburgh, fearing a miscarriage, she "entreated him to have some regard to her condition." "Come on!' said he, 'in God's name, come on! If this baby dies, we can have more." "11 His callous indifference to her anxiety may have had a more sinister motivation since, in the sixteenth century, late miscarriage often led to the mother's death. ${ }^{12}$ Mary successfully defeated the rebel lords and three months later, on June 19, 1566, bore a son, James. Although Darnley failed to attend the Roman Catholic christening in December, Mary had exacted acknowledgement of legitimacy from him. ${ }^{13}$ When Mary pardoned one of the conspirators in Riccio's murder, Darnley retreated to Glasgow, where he fell ill. Mary persuaded him to return to Edinburgh, and there, in the house at Kirk o' Fields early in the morning of February 10, he died. There was a massive explosion at the house; Darnley was found without a mark on his body, dead, perhaps strangled, in the garden. The official Scottish response to the murder was the claim that the lives of both Queen and King had been aimed at in the explosion. "And those that are the authors of this evil, only just failed in destroying the Queen by the same means...."14 Mary's failure to pursue the murderers of the king with any vigor gave support to suspicions that she was implicated in the plot. Placards and ballads appeared in Edinburgh accusing Bothwell, Mary's supporter, of the murder. The murderers were not prosecuted by the Queen and Parliament, in sharp contrast to the treason trial three years earlier in which the dead body of Huntly was arraigned before both houses of Parliament and the throne of the queen. ${ }^{15}$ Lennox, Darnley's father, was allowed to bring a private prosecution for the death. Bothwell, the accused, was allowed to bring 200 retainers to the trial. Lennox, allowed six, prudently declined to attend and Bothwell was acquitted. In the following weeks, Bothwell "kidnapped" the Queen, a plot she seems to have condoned, received a divorce from his wife, as well as an annulment, which freed him to marry again. He and Mary 
were married on May 15, in a Protestant ceremony. A month later on June 15, at Carberry Hill, Bothwell was forced to flee, and Mary was taken back to the Provost's House in Edinburgh where the crowd howled all night outside her window, "Burn the whore," the standard epithet which controls and limits the exercise of power by women. ${ }^{16}$

Mary's willingness to condone her abduction by Bothwell and the haste of their marriage, explained by some as her thralldom to Bothwell, becomes more explicable if seen as necessitated by an inopportune pregnancy. During her ensuing imprisonment at Lochleven, Mary refused to repudiate Bothwell, insisting that such an act would illegitimize the child she was carrying. She claimed to be only seven weeks pregnant, carefully dating conception to two weeks after her wedding to Bothwell. ${ }^{17}$ A lengthier pregnancy would explain the desperate speed of the marriage. Guzman de Silva, the Spanish ambassador in London had reported in June that Mary was five months pregnant. ${ }^{18}$ While the Queen's ability to disguise a pregnancy from the time of Darnley's murder until her imprisonment at Lochleven seems unlikely - Randolph accurately reported her first pregnancy at five wecks - the turmoil after Darnley's murder, and particularly after Mary's abduction, might have interfered with the normal spy network. Even Antonia Fraser, Mary's modern apologist, admits that the pregnancy might have preceded the wedding to Bothwell. Mary miscarried at Lochleven between July 18 and 24 , of twins, she claimed later to her physician Nau. While Mary might have inserted the detail - "deux enfants" - into Nau's text as a direct challenge to the childlessness of Elizabeth I and a boast of her own fecundity, such an interpretation seems improbable. While twin fetuses could be identified after eight weeks, they would be even more readily identifiable after a longer gestation, suggesting a conception that preceded the wedding. ${ }^{19}$ The miscarriage at Lochleven modified Mary's resistance to the rebel lords and she resigned her crown in favor of her son.

This story turns on the reproductive capacity of a woman. Mary's success in childbirth produced an alternate ruler, one much more available as a puppet and one unable to produce rival claimants to rule for at least twelve years. Mary's marriage to Bothwell, while binding an instrument of vengeance to her, provided legitimacy for her second pregnancy. The union of the sovereign with the suspected murderer of the king consort was repugnant to her subjects. The unruly body of the woman ruler had to be constrained. Within a year of her abdication, Mary had escaped to the protection of her cousin Elizabeth in England where she was imprisoned for seventeen years and finally executed for treason. The rebel lords who forced Mary's abdication justified their actions of rebellion against their 
sovereign by claiming her sexual indiscretion. Once her sexual guilt was affirmed, any action on their part was legitimated, for the adulterous woman violates the community of male sovereignty.

The process of legitimizing rebellion against a sovereign queen is evident in one early literary response to Darnley's murder, namely, the play, Horestes, which was written and performed in London after the murder and before Mary's flight to England. The play echoes comparisons between Mary and Clytemnestra made in ballads published in Scotland immediately after the murder. Those ballads elide the actual unattractive facts of Darnley's behavior and transform him into a paragon, ruthlessly slaughtered by a cruel wife. ${ }^{20}$ Such assumptions also inform John Pikeryng's Horestes, printed in London by William Griffith. ${ }^{21}$ This may be the same as the play Orestes, performed at court at "the Christmas or Shrovetide festivities of 1567-8." 22 Both J. E. Phillips, who has done extensive work on the propaganda surrounding the figure of Mary, and F. P. Wilson believe that the Revels account refers to Pikeryng's play. ${ }^{23}$ The Revels account makes clear the prevalence of the analogy between Mary and Clytemnestra, for it calls Orestes the "Scottish Kings play." 24 The Revels account records the presentation at the English court of a work condemning Mary as an adulteress, an entertainment coincidental with the Scottish Parliament's promulgation of an act condemning Mary for conspiracy in the murder of Darnley. ${ }^{25}$ It seems likely that the Orestes performed at court is the Horestes published in 1567, and forms part of the English propaganda effort to justify the deposition of a neighboring queen.

Horestes is a very cheerful, hybrid morality, recounting in thirteen scenes the story of Horestes' vengeance on his mother. It has a Vice who disguises himself as Revenge, a number of comic characters, and culminates in a happy ending - the coronation of Horestes by Truth and Duty and his wedding to Hermione. It is based on the material of the Oresteia, via Caxton's Receuil of the Historye of Troye, and is filled with songs - a sort of early musical comedy version of a revenge play.

This play makes explicit the problems posed to the son by the body natural of an adulterous and murderess mother. The play asks whether the tyranny of the mother erases the obligations to the body of the mother that the son has incurred in the natural processes of gestation, childbirth, and lactation. These questions form the core of four scenes: two colloquies with advisors, and then in two debates with female figures, culminating in Clytemnestra's plea for herself. In these four scenes, the claims of natural law are separated from and subordinated to the claims of what is held to be justice. 
From his first words, Horestes is presented as a character in conflict over the demands of justice and the obligations of pity. Pity becomes a quality projected onto a female figure, Dame Nature, who then instructs him in appropriate feeling.

To caull to minde the crabyd rage of mothers yll attempt Provokes me now all pyttie quight, from me to be exempt: Yet lo dame nature teles me that, I must with willing mind Forgive the faute and to pytie, some what to be inclynd. (A.iv.')

Against that pity, he sets the "terrible mother" the adulterous whore who has killed his father and threatened his life. There is no mention of Iphigenia; Clytemnestra's vengeance for her daughter is erased from the text. The triangle of father-mother-son simplifies the analogy between Darnley-Mary-James and also allows a simple opposition between natural law and paternal law to be developed in the play. (Clytemnestra's vengeance for the sacrifice of her daughter provides some justification for the wife's rebellion and taints Agamemnon with a violation of natural law himself.) The implication that Clytemnestra's activities were solely motivated by adulterous lust - in Pikeryng's play she is frequently called the "adulltres dame" - is part of the wider Protestant propaganda effort condemning Mary for her association with Bothwell and implying her responsibility for the murder of Darnley.

Significantly, in his first appearance, Horestes seeks advice from the gods of war. While some distress over his mother is acknowledged, his participation in the masculine pursuits of war is predicated on her execution. The implication that manliness is defined by the destruction of the mother is given some ambiguity by the dubious veracity of the Vice, who claims to be sent by the gods and who defines courage as the eradication of childish pity for the mother: "Put of that childish love" (B.i.). Despite the ambiguity over the status of the advice given to Horestes, the happy ending of the play confirms the correctness of the Vice's message. Horestes does demonstrate his chivalric potential by banishing pity for his mother and ordering her execution. He is rewarded with a crown and a bride.

Horestes does not rely solely on the message from the gods, but seeks instruction from King Idumeus, ruler of Crete. Idumeus provides an exemplary model of kingship by immediately secking advice from his council. The character named Councell considers vengeance appropriate:

As I do thinke my soferayne lord, it should be nothing ill, A Prynce for to revenged be, on those which so dyd kyll. His fathers: grace. (B.ii.) 
Not only is vengeance appropriate, but it is also a necessary preventative against further murders by regicides. Intriguingly, Councell's advice both emphasizes the link between father and son - Prince and father's grace and erases the prince's connection with the murderess. In fine bureaucratic fashion, the clause "on those which so dyd kyll" conveniently blurs the maternal status of the murderess and evades the question of natural law. Idumeus immediately accepts this advice, encourages Horestes' vengeance and offers an army to assist. In a subsequent colloquy between Councell and King, they discuss Horestes' manly potential and his paternal heritage. Idumeus sees him as following in "his fathers steppes" (B.ii.") and Councell concurs only to elevate him to the imitator of Achilles himself, the greatest Greek hero. Councell not only hides the body of the mother from consideration but also elevates matricide to the highest level of chivalry.

This careful development of the prince's manliness and chivalric potential shifts attention away from any natural bond between mother and son and replaces that blood link with the patriarchal bond of father and son and the chivalric bond between young aspirant and great hero. The notion of entrance into manhood, a ritual initiation through war, is the burden of the subsequent comic scene between two squires of the court who resolve to follow Horestes in battle, and then quarrel over their relative strength.

The struggle between natural law and paternal justice is given full expression in the ensuing scene when Dame Nature herself intercedes for the mother. Horestes' prayer at the head of his army again presents him as the executor of paternal law against the "adultress dame." Nature enters to protest. Her argument is rooted in the principle that the obligations incurred by the child to the mother's body through the processes of pregnancy, birth, and lactation prohibit the exercise of violence against the mother. Nature supports her argument with examples from the behavior of animals; even tigers do not harm their own:

The cruel beasts that raung in feldes whose iause to blod ar whet Do not consent their mothers paunch, in cruell wise to eate. (B.iv.')

Her final reason, more threat than argument, warns of the harm to his reputation that will ensue. Against the debts of nature and the pain of childbirth, Horestes offers abstract arguments of law. A mother who has offended the laws of god and man must be punished. The prince as the executor of public law - human and divine - cannot be called tyrant even when he sheds his mother's blood. Even Nature's final threat - the danger of a reputation as sullied as that of Oedipus, parricide - does not deter Horestes: 


\section{2 / Renaissance and Reformation}

For this is true that bloud for bloud, for my fathers deth doth crave And lawe of godes, and lawe of man, doth eke request the same. (B.iv.")

The laws of god and man override the claims of nature.

Dame Nature's grave piety contrasts strongly with the reckless abandon of Clytemnestra, first presented singing a love song with her lover Egistus. (One hardly thinks of Bothwell as engaged in song, but inevitably one is reminded of David Riccio, who was a fine musician.) In their song, the lovers establish an analogy between their love and that of Helen and Paris. The mother is thus presented as one inappropriately consumed by the fires of passion and recklessly indifferent to the arrival of her son: "and for his forse, I sure set not a pyn." (C.iii. $\left.{ }^{\mathrm{v}}\right)$. Clytemnestra's dangerous indifference extends to the citizens of her city, for her resistance provokes Horestes to command the sack of the city and the death of all, save his mother. Clytemnestra is demonstrating the attributes of a tyrant - reckless lust and indifference to the welfare of her subjects.

Clytemnestra, when brought before her son, attempts to play on the pity of her child. Her pleas attempt to assert the blood link between mother and son: "Yf aney sparke of mothers bloud, remaynd within thy breste / Oh gratious child let now thine eares, unto my words be prest" (D.i. ). The play presents the transition of the son from childhood into manhood, and in the process the suppression of all acknowledgment of maternal blood. The mother's plea fails, and the father's vengeance prevails. Although the son does feel some pity, it is provoked by his recognition of an emblem of de casibus tragedy, and not by the claims of natural law:

By all the godes my hart dyd fayle, my mother for to se

From hye estate for to be brought, to so great myserey. (D.i.)

His own participation in the operations which have removed his mother from high estate is entirely elided.

Horestes demonstrates his full entrance into manhood and his potential capacity as ruler by his ability to condemn his mother to execution and by his secure confidence in his reputation. To Clytemnestra's warning that he will acquire the fame of Edyppus and Nero, he demonstrates a capacity to quote authorities - Juvenal and Socrates - who support his determination to punish those who live licentiously. Execution of the mother has been successfully transmuted from an argument based on natural law to one involving patriarchal law. Execution of the mother becomes a necessary support of good government. Paternal law supersedes natural pity. 
The difficulties in the containment of blood feuds - the resurgence of the claims of kin links - is exposed by the immediate arrival of Menalaus to execute revenge for his sister (actually his wife's sister). Menalaus reopens the conflict of paternal law and nature, but is persuaded by Idumeus and Nestor to create peace in the feud by offering, in marriage, the body of another woman, Menalaus' daughter, Hermione. The play ends with the wedding of the young lovers, Hermione a far more docile and benevolent queen than Clytemnestra.

The play offers several pointed instructions to its regal audience, Elizabeth. It explores justifications for interference in the affairs of another state and condones deposition of a queen without undermining sovereign power entirely by defining Clytemnestra as an adulterous woman and tyrant, thus one who has forgone all respect as a ruler. It also offers a pointed model for a ruler's adherence to the advice of council. At the same time, it offers a submerged warning that contradicts that overt policy of Elizabeth's council. At a time when her council and subjects were zealously urging on Elizabeth the advantages of marriage and reproduction, this play exposes the difficulties at the intersection of monarchy and maternity. Female rule is presented in this play as dangerous and in need of subordination to male authority. Hermione, the ideal queen consort, speaks six lines in which she submits herself "with humble harte" to her husband. A queen consort fits far more readily into Tudor depictions of female rule than a queen regnant.

In addition to the contradictions of the play's appeal for its regal audience, Horestes has an oddly prophetic aspect, for the dilemma adumbrated - the problem of Horestes before his adulteress mother - was the problem that revived nearly twenty years later when Mary Queen of Scots was tried for treason and faced execution. James, unwilling to forgo his English pension, and unwilling to anger the woman he hoped to succeed, was a reluctant correspondent in the diplomatic flurry which followed the judgment against Mary. James was in a quandary. Although he had not seen Mary since babyhood, he was bound to her by the institution of natural law which named her his mother and he feared the opprobrium of Europe if he failed to protest against her execution. His own awareness of the maneuvering he was forced into is betrayed when, in a letter to Elizabeth, he begs her "not to take me to be a chameleon." 26

In a letter to Leicester, he protests "the pretended condemnation of the Queen my mother." 27 Yet this open avowal of the relationship between himself and the mother is quickly followed by his expression of concern over the infringement of his honor. "As for my own part, it is far by my expectation or deserts that your countrymen, in so using the mother, should 
have borne so small respect to the offspring...."28 Execution of the mother is reconstructed as an insult to the son.

The link between his mother and his honor recurs in a second letter to Leicester, as James, fearful that the provisions of the Bond of Association, which barred inheritance of the throne by anyone who intended to benefit from an assassination of Elizabeth, and that person's heirs, attempted to clear himself of blame. James denies any communication with his mother and separates himself from her claim to the English throne. "But, specially, how fond and inconstant I were if I should prefer my mother to the title let all men judge. My religion ever moved me to hate her course, although my honour constrains me to insist for her life." 29

In his final plea to Elizabeth for his mother's life, he presses the claims of sovereignty and blood, yet in the process defines Mary as more nearly allied to Elizabeth than to himself: "What thing, madame, can greatlier touch me in honour that [am] a king and a son than that my nearest neighbour, being in straitest [friend]ship with me, shall rigorously put to death a free sovereign prince and my natural mother, alike in estate and sex to her that so uses her, albeit subject I grant to a harder fortune, and touching her nearly in proximity of blood." ${ }^{30}$ The phrase, "my natural mother," tucked so neatly before the extended comparison between Mary and Elizabeth suggests that the kinship of queens is far greater than any natural link between mother and son. We catch James here in the process of constructing an alternate system of royal kinship-links that transcend the merely natural bonds between mother and son. That process continues in the salutation that closes the letter accepting Elizabeth's denial that she intended Mary's death. He requests that his cousin provide an honorable way out for both of them: "And as for my part I look that ye will give me at this time such a full satisfaction in all respects as shall be a mean to strengthen and unite this isle, establish and maintain the true religion, and oblige me to be, as before I was, your most loving and dearest brother." 31 It is far better to be the brother and heir of the living queen than to insist on responsibilities owed to the body of the natural mother, though, after his coronation, James did subdue any residual filial guilt by removing his mother's corpse from the tomb at Peterborough and reinterring it in Westminster Abbey near the tomb of the woman who signed her warrant of execution.

The play Horestes urges and condones a split between the laws of men and the laws of nature when an act of vengeance taken directly by the son on the body of the mother is condoned. Yet in James's letters surrounding the execution of his mother, the claims of natural law and the potential dishonor for a son who condones the death of his mother worryingly fail 
to be subdued. In the play, the claims of natural law and the ambiguity implicit in the approval of the gods are made explicit in the arrival of Menalaus when he comes to avenge his sister. While the laws of gods and men may condone execution of the mother, the claims of blood are not quieted; the potential for social chaos implicit in the blood feud continues. The feud is ended only by the exchange of the body of another woman, the daughter given in marriage. Hermione - the potential mother - is substituted for the body of the dead mother and the play ends in harmony.

Constance Jordan rightly sees as positive the developments in Renaissance political theory which enabled men to conceptualize woman's rule. She describes those developments as part of the defenses of women which "argue for the creation of societies in which what is deemed natural is recognized as an expression of historically contingent cultural norms." 32 Yet that positive development is connected to a disturbing suppression of natural law. Natural law grants to the bodies of women in their reproductive capacity certain privileges which are gender specific. Theoretical developments which eliminate those aspects of the body which inhere only in reproducing female bodies produce an appearance of gender neutrality, but actually maintain the androcentric definitions of law and sovereignty. The teasing claims of natural law which fail to be fully subdued either in the play, Horestes, or in the mind of the son of Mary Queen of Scots must be accommodated in a fully inclusive definition of law and justice.

\section{Vassar College}

\section{Notes}

I would like to acknowledge the helpful comments of Carole Levin, James Lewton-Brain, Elizabeth Robertson, and Paul Russell.

1 Conyers Read, Mr. Secretary Cecil and Queen Elizabeth (London: Cape, 1955), p. 378.

2 See Ernst Kantorowitz, The King's Two Bodies: A Study in Mediaeval Political Theology (Princeton: Princeton University Press, 1957) for extensive exploration of this concept in medieval church ritual and canon laws. See also Marie Axton, The Queen's Two Bodies (London: Royal Historical Society, 1977).

3 Constance Jordan, "Woman's Rule in Sixteenth-Century British Political Thought," Renaissance Quarterly 40 (1987), 421-451. Jordan considers the problems facing the Tudor queens regnant, but does not extend her analysis to Mary Queen of Scots.

4 This narrative of events follows that in Alison Plowden, Elizabeth Tudor and Mary Stuart: Two Queens in One Isle (Totowa, N.J.: Barnes, 1984) and Antonia Fraser, Mary Queen of Scots (New York: Delacorte, 1969), with additions as indicated.

5 Fraser, p. 240.

6 Fraser, pp. 230, 232.

7 William Drury to Cecil, March 27, 1567, CSP Foreign Elizabeth 1566-1568, ed. Allan Crosby (London: Longman, 1871), p. 39. 


\section{6 / Renaissance and Reformation}

8 M. De Foix to Cecil, March 23, 1567, summarized in CSP Foreign Elizabeth 1566-1568: "Was horrified by the contents of his letter, as nothing could be more dreadful than that a deformed and base menial should be caught in the act of adultery with the Queen and slain by her husband, who then should have secretly deserted his friends," p. 37.

9 Read, p. 346.

10 Plowden, p. 105. See also Fraser, p. 253.

11 Claude Nau, Memorials of Mary Stewart, ed. J. Stevenson (Edinburgh, 1883), cited in M. H. Armstrong Davison, The Casket Letters (Washington, D.C.: University Press of Washington D.C., 1965), p. 27.

12 For a discussion of the perils of childbirth in Scotland in the Renaissance, see Rosalind K. Marshall, Virgins and Viragos: A History of Women in Scotland from 1080-1980 (Chicago: Academy, 1983), pp. 105-122.

13 Fraser, p. 268.

14 Letter from Mary's Council to Catherine de Medici on February 10, 1567, immediately after the murder, quoted in Davison, p. 274.

15 Fraser, p. 201.

16 Allison Jaggar, "Prostitution," in Women and Values: Readings in Recent Feminist Philosophy, ed. Marilyn Pearsall (Belmont, California: Wadsworth, 1986), pp. 108-121.

17 Throckmorton to Queen Elizabeth, July 18, 1567, CSP Foreign Elizabeth 1566-68, p. 288.

18 Fraser, p. 343.

19 Fraser, p. 343.

20 See J. E. Phillips, Images of a Queen (Berkeley: University of California Press, 1964), pp. 41-44.

21 All quotations from Horestes are taken from the facsimile edition by Daniel Seltzer, The Interlude of Vice (Horestes) (Oxford: Malone Society Reprints, 1962). My edition with J. Anne George (Galway: National University Press of Ireland) is forthcoming.

22 F. P. Wilson, The English Drama 1485-1585 (Oxford: Clarendon, 1969), p. 144.

23 Wilson, p. 144 and Phillips, p. 46. See also J. E. Phillips, "A Revaluation of Horestes (1567)," Huntington Library Quarterly 18 (1955): 227-244. One problem with assuming identity between the two is that the Revels records list payments for a number of sets, houses actually, which do not appear in the printed text we have, though that text has extensive stage directions.

24 Wilson, p. 144.

25 Davison, pp. 78-79, Fraser, p. 352.

26 Letter from James to Elizabeth, G. P. V. Akrigg, ed. Letters of King James VI and I (Berkeley: University of California Press, 1984), p. 83.

27 Akrigg, p. 76.

28 Akrigg, p. 76.

29 Akrigg, p. 78.

30 Akrigg, p. 82.

31 Akrigg, pp. 84-85.

32 Jordan, p. 451. 